\title{
Aerosol Pollution Characterization before Chinese New Year in Zhengzhou in 2014
}

\author{
Xiuli Wei ${ }^{1 *}$, Huaqiao Gui ${ }^{1,3}$, Jianguo Liu ${ }^{1,3}$, Jie Zhang $^{2}$, James Schwab ${ }^{2}$, Minguang Gao ${ }^{1}$ \\ ${ }^{1}$ Key Laboratory of Environmental Optics and Technology, Anhui Institute of Optics and Fine Mechanics, Chinese \\ Academy of Sciences, Hefei 230031, China \\ ${ }^{2}$ Atmospheric Sciences Research Center, University at Albany, State University of New York, Albany and Wilmington, NY, \\ 12222, USA \\ ${ }^{3}$ CAS Center for Excellence in Regional Atmospheric Environment, Institute of Urban Environment, Chinese Academy of \\ Sciences, Xiamen 361021, China
}

\begin{abstract}
Fourier-transform infrared (FTIR) spectroscopy is a useful and nondestructive method for measuring the current atmospheric concentrations of inorganic compounds (sulfate, nitrate, and ammonium) and has been extensively used for environmental monitoring since the 1980s. In this study, we used FTIR spectroscopy to measure the inorganic compounds in particulate matter with a diameter of less than $2.5 \mu \mathrm{m}$ and combined the data of gaseous pollutants $\left(\mathrm{NO}_{2}\right.$ and $\left.\mathrm{SO}_{2}\right)$ to analyze the inorganic compounds in $\mathrm{PM}_{2.5}$ from January 24 to January 31, 2014, in Zhengzhou. The measurement period was divided into three pollution stages. During Stage 1 (January 24-26), the low-pollution stage, wind from the east of Zhengzhou caused the pollutants to rapidly disperse and the haze to clear. During Stage 2 (January 26 to the noon of January 30), transported emissions were the main contributor to the high sulfate concentration, as indicated by the poor correlation between the sulfur oxidation ratio (SOR) and the $\mathrm{SO}_{4}{ }^{2-}$ concentration $\left(\mathrm{R}^{2}=0.45\right)$. Nitrate was formed through homogeneous gas-phase reactions of $\mathrm{NO}_{2}$ with $\mathrm{OH}$ or $\mathrm{O}_{3}$, resulting in $\mathrm{HNO}_{3}$ in the $\mathrm{PM}_{2.5}$, as indicated by the good correlation between the nitrogen oxidation ratio (NOR) and the $\mathrm{NO}_{3}{ }^{-}$concentration $\left(\mathrm{R}^{2}=0.91\right)$. During Stage 3 (the afternoon of January 30 to January 31 ), the average concentration of the $\mathrm{PM}_{2.5}$ increased from approximately $140 \mu \mathrm{g} \mathrm{m}^{-3}$ to $260 \mu \mathrm{g} \mathrm{m}^{-3}$, and the concentrations of sulfate, nitrate, and ammonium decreased from $37.62 \mu \mathrm{g} \mathrm{m}^{-3}, 56.63 \mu \mathrm{g} \mathrm{m}{ }^{-3}$, and $34.63 \mu \mathrm{g} \mathrm{m}^{-3}$ to $32.14 \mu \mathrm{g} \mathrm{m}^{-3}, 31.14 \mu \mathrm{g} \mathrm{m}^{-3}$, and $26.35 \mu \mathrm{g} \mathrm{m}^{-3}$, respectively. The high levels of $\mathrm{PM}_{2.5}$ during this stage may have been caused primarily by the hygroscopic growth of particles.
\end{abstract}

Keywords: FTIR; Inorganic compounds; $\mathrm{PM}_{2.5}$; Hygroscopic growth.

\section{INTRODUCTION}

Particulate pollution is globally recognized as a pertinent issue due to its adverse effects on health, air quality, regional visibility, and climate change (Pope and Dockery, 2006; Tai et al., 2012; Zhang et al., 2015). China has experienced severe air pollution in the past two decades (Tie and Cao, 2009). Moreover, in recent years, aerosol concentrations across China have been at extremely high levels (Chang et al., 2017). According to reports, annual $\mathrm{PM}_{2.5}$ concentrations are up to six times higher than the national air quality standard in some megacities in northern China (Tao et al., 2017). Currently, an increasing number of studies have

\footnotetext{
* Corresponding author.

Tel.: 180-5511-5550; Fax: 0551-65593693

E-mail address: xlwei@aiofm.ac.cn
}

investigated the sources and formation mechanisms of aerosols, with the aims to decrease regional air pollution (Sun et al., 2014; Zhang et al., 2017) and to resolve these environmental issues to protect human health.

Determining the characteristics and sources of particulate matter with a diameter of less than $2.5 \mu \mathrm{m}\left(\mathrm{PM}_{2.5}\right)$ is of vital concern for controlling air pollution. Previous studies have indicated that $\mathrm{PM}_{2.5}$ is formed from primary fine particles and through secondary formation from gaseous precursors. Currently, studies are being conducted to ascertain the characteristics of $\mathrm{PM}_{2.5}$ to identify the pollution source. The pollution sources are regional transport and local production. Regional transport, in particular, has been one of the most crucial factors contributing to heavy haze pollution in China (Chan and Yao, 2008; Xiao et al., 2011; Liao et al., 2014; Wang et al., 2014). The majority of locally produced pollution has been identified as a result of traffic exhaust, fossil aerosol, secondary aerosol, dust, and other sources (Tian et al., 2016; Hang et al., 2017; Li et al., 
2017; Shang et al., 2018). Occasionally, pollution sources vary seasonally. Fireworks are a critical source of pollution due to their use during important cultural festivals. Firework burning emits a considerable amount of gaseous pollutants $\left(\mathrm{SO}_{2}, \mathrm{NO}_{\mathrm{x}}\right.$, etc.) and fine particles comprising organic and elemental carbon, sulfate, potassium, chloride, and various metals, which can cause health risks. Therefore, currently, an increasing number of studies have been conducted on pollution and fireworks (Wang et al., 2007; Jiang et al., 2015; Kong et al., 2015; Tian et al., 2014). During the Diwali festival in India, Ba, K, Al, and Sr levels were 1091, 25, 1, and 15 times higher than previous levels (Godri et al., 2010). Wang et al. (2007) revealed that more than $90 \%$ of the total mineral aerosol and $98 \%$ of $\mathrm{Pb}, 43 \%$ of total carbon, $28 \%$ of $\mathrm{Zn}$, and $8 \%$ of $\mathrm{NO}_{3}^{-}$in $\mathrm{PM}_{2.5}$ were from firework burning on the night of the Lantern Festival in 2006 in Beijing. Tian et al. (2014) reported that fireworks contributed to $29.66 \%$ of $\mathrm{PM}_{2.5}$ during the heavy-firework period and $7.18 \%$ during the light-firework period with PMF (Positive Matrix Factor) analysis. Kong et al. (2015) indicated that the intensive emission of firework particles on New Year's Eve accounted for $60.1 \%$ of $\mathrm{PM}_{2.5}$ in Nanjing in 2014. Jiang et al. (2015) found that the peak concentration of $\mathrm{PM}_{2.5}$ during the LNY (Lunar New Year) was $775 \mu \mathrm{g} \mathrm{m}^{-3}$, which is more than ten times higher than the Chinese National Ambient Air Quality Standard.

Zhengzhou is the capital of Henan Province, which is a developing region, and as a result, it is heavily polluted with high levels of particles, which have a negative effect on the environment and climate. Due to its key position in national transportation, communication, and energy, Zhengzhou has suffered from haze pollution since 2013, According to Greenpeace rankings in 2013, Zhengzhou is one of the top 10 cities worldwide in terms of $\mathrm{PM}_{2.5}$ concentrations. Wang et al. (2016) studied secondary $\mathrm{PM}_{2.5}$ in Zhengzhou and revealed that ammonium sulfate and ammonium nitrate were the main factors contributing to poor visibility in Zhengzhou. Wang et al. (2017) examined the characteristics and origins of air pollution in 2013 and revealed that regional transport made a considerable contribution to $\mathrm{PM}_{2.5}$ pollution based on observations and hybrid receptor models. Wang et al. (2018) demonstrated heavy atmospheric pollution in winter in Zhengzhou, with pollution episodes due to transportation. Geng et al. (2013) studied the chemical composition and source apportionment of $\mathrm{PM}_{2.5}$ in Zhengzhou in 2010. They revealed that soluble ions, total carbon, and elements contributed $41 \%, 13 \%$, and $3 \%$ of $\mathrm{PM}_{2.5}$ mass, respectively, and they revealed soil dust, secondary aerosols, and coal combustion were the three major sources which contributed $26 \%, 24 \%$, and $23 \%$ of the $\mathrm{PM}_{2.5}$ concentration, respectively. In 2015 the Department of Environmental Protection of Henan Province published the results of $\mathrm{PM}_{2.5}$ source apportionments, which indicated that dust was the largest source of $\mathrm{PM}_{2.5}$ in the urban area of Zhengzhou, with a contribution of $24.5 \%$, and industry, coal, and vehicle emissions were also contributing factors. Jiang et al. (2017) also studied the chemical composition characteristics of $\mathrm{PM}_{2.5}$ in Luoyang, Zhengzhou, and Pingdingshan from October 2014 to July 2015; they indicated that coal-fired sources and vehicles were two main contributors to air pollution.

The aforementioned studies have provided some results related to air pollution from fireworks in big cities in the world, particularly in China. However, for Zhengzhou, few studies have examined pollution from fireworks and how they affect air pollution under complex meteorological conditions.

In this study, a Fourier-transform infrared (FTIR) spectrometer using an attenuated total reflectance (ATR), along with the collection instrument, was deployed in Hefei to analyze the samples which were collected in Zhengzhou during January 24-31. The inorganic composition of $\mathrm{PM}_{2.5}$ was quantified based on the absorption peaks. The pollution characteristics of $\mathrm{PM}_{2.5}$ were analyzed to determine the different factors influencing air pollution during three stages (according to the pollution characteristics and the meteorological condition, the measurement period was divided into three stages). The concentrations of $\mathrm{SO}_{2}$ and $\mathrm{NO}_{2}$ were combined to study the formation mechanism of aerosols. The effects of fireworks and transport-related emissions on the environment were also investigated using back trajectories to determine the transportation source. These findings will benefit government environmental agencies and will provide some clues to the Chinese government about management strategies for restricting the time of setting off fireworks.

\section{METHODS}

\section{Sampling Site and Measurement Site}

$\mathrm{PM}_{2.5}$ aerosols (every 4 hours) were collected on $3 \mathrm{~cm} \times$ $3 \mathrm{~cm}$ glass fiber filters at $16.7 \mathrm{~L} \mathrm{~min}^{-1}$ in a volume sampler equipped with a $\mathrm{PM}_{2.5}$ inlet from January 23 to January 31 in 2014. The sampling site is situated on the roof of a sixstory building of the Department of Environmental Protection of Henan Province located in the middle of Zhengbian Road, Jinshui District, Zhengzhou City $\left(113.42^{\circ} \mathrm{E}, 34.44^{\circ} \mathrm{N}\right)$. This study was conducted in winter and just before Chinese New Year. Haze, as usual, was more severe during this period. Fig. 1 provides the location of the collection site.

The measurement site is located at Key Laboratory of Environmental Optics and Technology, Anhui Institute of Optics and Fine Mechanics, Chinese Academy of Sciences, which is located in the northwest section of Hefei city $\left(117.17^{\circ} \mathrm{E}, 31.52^{\circ} \mathrm{N}\right)$, Anhui Province. All of the samples were transported to the measurement site and were analyzed.

\section{FTIR Analysis}

In this experiment, all of the samples were analyzed using Fourier-transform infrared spectrometer (Tensor 27) with an attenuated total reflectance accessory (ATR-FTIR) and MCT detector. The spectra were collected by averaging 64 scan times over the mid-infrared wave number from 400 to $5000 \mathrm{~cm}^{-1}$. And quantify the spectral signals to obtain the mass of the sulfate, nitrate, and ammonium ions after baseline correction and zeroing using non-linear least square method. Quantitative analysis of the filter surface 

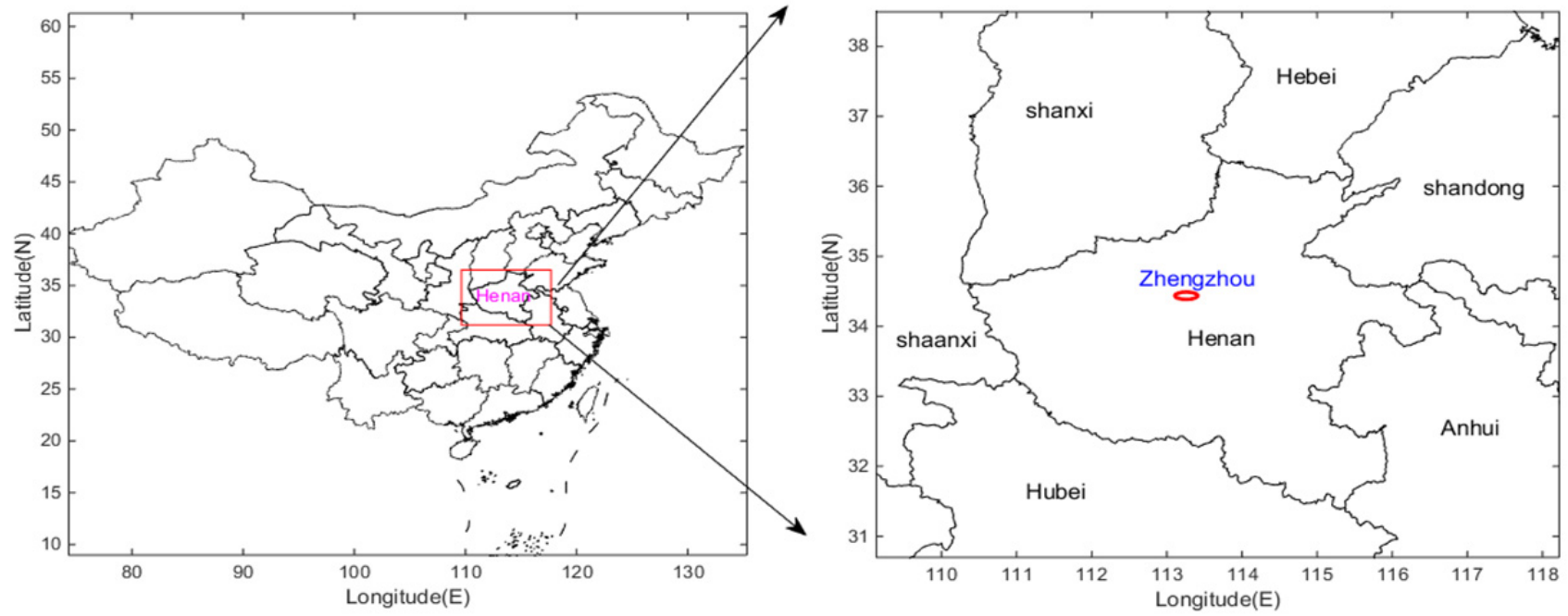

Fig. 1. The location of the collection site.

was performed directly without any treatment of the filter. The sulfate, nitrate, and ammonium ions were identified and quantified based on Table 1 (Reff et al., 2005).

\section{Air Mass Trajectories}

Twenty-four-hour air mass back trajectories arriving at Zhengzhou were calculated every 4 hours over the study period by using the National Oceanic and Atmospheric Administration (NOAA) Hybrid Single Particle Lagrangian Integrated Trajectory (HYSPLIT) 4.8 model and the meteorological input from the Air Resources Laboratory FNL data (Final Analysis) archive. These data were used to study the transport processes of air pollution and trace pollution sources and the routes of transport. Zhengzhou was the ending location. The ending height of $500 \mathrm{~m}$ was chosen to investigate the influence of longrange transport as it is likely independent of the local wind patterns caused by the structure of the building.

\section{Meteorological Parameters and Air Quality Data}

The temperature, humidity, and wind speed were downloaded from Weather Underground (https://www.wun de rground.com/); $\mathrm{AQI}, \mathrm{SO}_{2}, \mathrm{NO}_{2}$, and $\mathrm{PM}_{2.5}$ concentrations in Zhengzhou were collected from China National Environmental Monitoring Center http://106.37.208.233:2 0035/). The data were published by the China National Environmental Monitoring Centre.

\section{RESULTS AND DISCUSSION}

\section{Spectral Characteristics of Inorganic Ions in Aerosols}

$\mathrm{PM}_{2.5}$ samples were collected on filters, then analyzed using an ATR-FTIR spectrometer. The wave numbers of samples spectra were from 600 to $5000 \mathrm{~cm}^{-1}$ with a resolution of $4 \mathrm{~cm}^{-1}$. The ATR-FTIR spectral characteristics of one sample are displayed in Fig. 2. In this analysis, we mainly focused on the spectrum of inorganic compounds (sulfate, nitrate, and ammonium ions), as many researchers have reported that inorganic species constitute a considerable part of $\mathrm{PM}_{2.5}$, and that sulfate, nitrate, and ammonium ions are the major ionic components of $\mathrm{PM}_{2.5}$ (He et al., 2001; Lin, 2002; Bardouki et al., 2003; Mouli et al., 2003).

Characteristic spectrum peaks of different inorganic compounds are required to calculate their concentration. For nitrate, the symmetric stretching band appears at approximately $1045 \mathrm{~cm}^{-1}\left(v_{1}\right.$; Raman activity), the symmetric bending band at about $825 \mathrm{~cm}^{-1}$ ( $v_{2}$; infrared activity), the asymmetric stretching band at approximately $1370 \mathrm{~cm}^{-1}$ ( $v_{3}$; infrared activity and Raman activity), and the asymmetric bending band at approximately $723 \mathrm{~cm}^{-1}$ (v4; infrared activity and Raman activity) (Liu et al., 2005). At the same time, the $\mathrm{v}_{\mathrm{S}}\left(\mathrm{NO}_{3}{ }^{-}\right)$mode of pure $\mathrm{NH}_{4} \mathrm{NO}_{3}$ salt appears at $828 \mathrm{~cm}^{-1}$. Liu et al. (2005) reported that a symmetric bending band of $\mathrm{NO}_{3}^{-}$in the spectrum of aqueous $\mathrm{NH}_{4} \mathrm{NO}_{3}$ is located at $830 \mathrm{~cm}^{-1}$ and the mode is infrared active. Their results are comparable with those of the present study, as 825 and $1321 \mathrm{~cm}^{-1}$ are the symmetric bending band and asymmetric stretching band of nitrate, respectively. Because the peak of $825 \mathrm{~cm}^{-1}$ was not disturbed by other peaks, it was chosen to quantify the nitrate concentration in this study.

For sulfate, the strong peak observed at $1074 \mathrm{~cm}^{-1}$ in the "regular" spectrum, as shown in Fig. 2, and the shoulder located at approximately $1044 \mathrm{~cm}^{-1}$ in the "sandy" spectrum were assigned to the $\mathrm{n}_{3}$ asymmetrical stretching vibration of free sulfate ions in the solution (Hug, 1997; Peak et al., 1999). Vibrational frequencies of ammonium ions at 1413,3045 , and $3215 \mathrm{~cm}^{-1}$ were confirmed by the reported frequencies at approximately 1400 and $3200 \mathrm{~cm}^{-1}$ (Allen et al., 1994; Bishop et al., 2002; Maria et al., 2002). $\mathrm{N}-\mathrm{H}$ bond absorbance bands at approximately 3210 and $3080 \mathrm{~cm}^{-1}$ were observed in the amino acid and amine spectra (from $\mathrm{NH}_{2}$ ) as well as in the ammonium sulfate and nitrate spectra (from $\mathrm{NH}_{4}{ }^{+}$) (Coury and Dillner, 2008), and these were considered the $\mathrm{v}_{\mathrm{as}}\left(\mathrm{NH}_{4}{ }^{+}\right)$and $\mathrm{v}_{\mathrm{s}}\left(\mathrm{NH}_{4}{ }^{+}\right)$ modes, respectively (Kadir et al., 2011). The observed peak of ammonium was $1412 \mathrm{~cm}^{-1}$. In this study, we also used the $1412 \mathrm{~cm}^{-1}$ to quantify the ammonium concentration 
Table 1. ATR - absorption frequencies and vibrational modes of observed species on $\mathrm{PM}_{2.5}$.

\begin{tabular}{lll}
\hline Wavenumber $\left(\mathrm{cm}^{-1}\right)$ & Species & Vibration mode \\
\hline 825 & Nitrate & $v_{2}$ \\
1044 & Sulfate & $\mathrm{n}_{\text {asym }}\left(\mathrm{SO}_{4}\right)-\mathrm{n}_{3}$ \\
1074 & Sulfate & $\mathrm{n}_{\text {asym }}\left(\mathrm{SO}_{4}\right)-\mathrm{n}_{3}$ \\
1182 & Hydrogen sulfate & $\mathrm{C}_{3 \mathrm{v}}$ \\
1321 & Nitrate & $v_{3}$ \\
1412 & Ammonium & $\mathrm{NH}_{4}^{+}$deformation \\
3033 & Ammonium & $v_{2}+v_{4}$ \\
3186 & Ammonium & $v_{3}$ \\
\hline
\end{tabular}

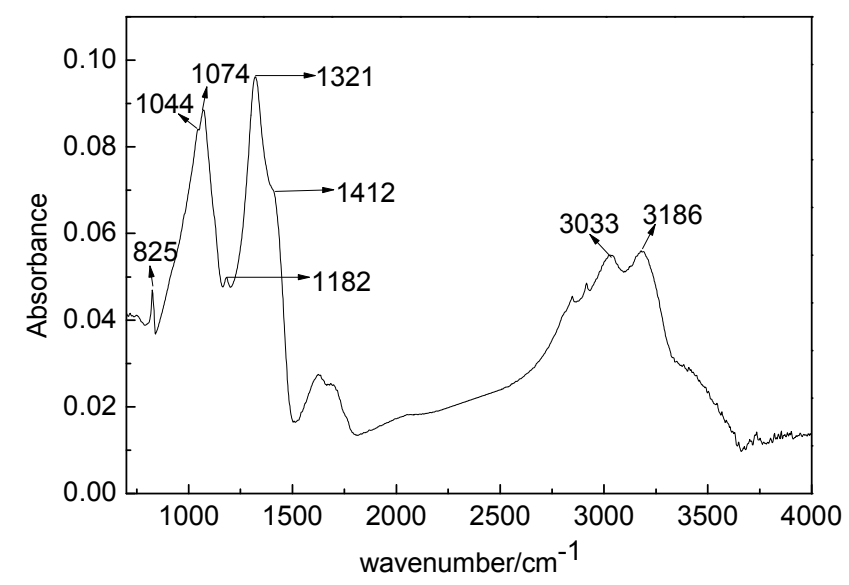

Fig. 2. FTIR-ATR spectra of $\mathrm{PM}_{2.5}$.

(Steven et al., 2002) because this peak was strong and only overlapped with the $1321 \mathrm{~cm}^{-1}$, while the peak of $3200 \mathrm{~cm}^{-1}$ was disturbed by C-H peaks (about $2920 \mathrm{~cm}^{-1}$ and $2850 \mathrm{~cm}^{-1}$ ) that would increase error (Liu et al., 2015). Tsai and Kuo (2006) described that bisulfate ions produce absorption peaks at $1182 \mathrm{~cm}^{-1}$. However, this peak was quite weak and was therefore not used for quantitative analyses in this study. Instead, through a simple procedure described in previous studies, quantitative analysis of the filter surface was performed directly without any treatment method.

\section{Daily Variation of Inorganic Ions in Aerosols}

To determine the air quality in Zhengzhou City during the measurement period, we downloaded the AQI data from China National Environmental Monitoring Center as depicted in Table 2. According to the Chinese Ambient Air Quality Standard designated by the Chinese Ministry of Environmental Protection (CMEP), air quality can be divided into six different levels based on different AQIs. Table 2 demonstrates that good air quality (moderate) was found only on January 26, and light pollution (unhealthy for sensitive groups) was observed on January 27 and 28. Moreover, moderate pollution (moderate haze) and heavy pollution (very unhealthy) occurred on January 25 and 29 and on January 24 and 30, respectively, and severe pollution (hazardous) was detected on January 31 .

Fig. 3 presents the daily variation of $\mathrm{PM}_{2.5}, \mathrm{NO}_{2}, \mathrm{SO}_{2}$, and $\mathrm{AQI}$ during the measurement period. The $\mathrm{AQI}$ accurately measures $\mathrm{PM}_{2.5}$, and both $\mathrm{AQI}$ and $\mathrm{PM}_{2.5}$ exhibited the lowest value $\left(69 \mu \mathrm{g} \mathrm{m}^{-3}\right.$ vs. $\left.50 \mu \mathrm{g} \mathrm{m}^{-3}\right)$ on January 26 and the highest value $\left(314 \mu \mathrm{g} \mathrm{m}^{-3}\right.$ vs. $\left.209 \mu \mathrm{g} \mathrm{m}^{-3}\right)$ on January 31 , showing that $\mathrm{PM}_{2.5}$ is the primary pollutant. The highest values of both pollutants were four times higher than the lowest value, which confirms the severity of this pollution. However, for $\mathrm{NO}_{2}$ and $\mathrm{SO}_{2}$, two time trends were observed against the variation of AQI. Before January 26, $\mathrm{NO}_{2}$ and $\mathrm{SO}_{2}$ decreased with a decrease in $\mathrm{AQI}$; however, after January 26, with an increase in AQI, no significant increases were observed in $\mathrm{NO}_{2}$ and $\mathrm{SO}_{2}$. Moreover, on January 31, when the AQI was highest (314), the concentrations of $\mathrm{NO}_{2}$ and $\mathrm{SO}_{2}$ were at their lowest levels (42 and $27 \mu \mathrm{g} \mathrm{m}^{-3}$, respectively), which was lower than the value of $\mathrm{NO}_{2}$ and $\mathrm{SO}_{2}$ (43 and $53 \mu \mathrm{g} \mathrm{m}^{-3}$, respectively) on the clean day (January 26).

Using the characteristic peaks of inorganic ions measured in the FTIR spectrum, we obtained the trends of inorganic ions (sulfate, nitrate, and ammonium) during the measurement period, as displayed in Fig. 4. Compared with the trend of inorganic ions (sulfate, nitrate, and ammonium) with the daily variation of $\mathrm{PM}_{2.5}, \mathrm{NO}_{2}, \mathrm{SO}_{2}$, and AQI, it was revealed that before January 26, inorganic ion concentrations followed the variations in $\mathrm{PM}_{2.5}$; however, after January 26, inorganic ion concentrations reached a peak on Jan 30 and then decreased on January 31. This trend was similar to that for $\mathrm{NO}_{2}$ and $\mathrm{SO}_{2}$. Different trends are considered to be related to the different formation mechanisms of aerosols. Based on the different trends exhibited by species during different periods, we classified the pollution process into three stages. Stage 1 was from January 24 to January 26, in which inorganic ions, pollutant gases, and $\mathrm{PM}_{2.5}$ followed the same decreasing trends; Stage 2 was from January 26 to the noon of January 30, in which inorganic ions followed $\mathrm{PM}_{2.5}$, but pollutant gases did not vary substantially; and Stage 3 was from January 30 to January 31, in which inorganic ions followed the decreasing trend of pollutant gases, while $\mathrm{PM}_{2.5}$ maintained an increasing trend.

\section{Stage 1 (January 24-26)}

Fig. 3 showed that the concentration of $\mathrm{PM}_{2.5}$, AQI, $\mathrm{SO}_{2}, \mathrm{NO}_{2}$, and $\mathrm{SO}_{4}{ }^{2-}, \mathrm{NO}_{3}^{-}$, and $\mathrm{NH}_{4}^{+}$decreased from January 24 to January 26. $\mathrm{PM}_{2.5}, \mathrm{AQI}, \mathrm{SO}_{4}{ }^{2-}, \mathrm{NO}_{3}^{-}$, and $\mathrm{NH}_{4}{ }^{+}$exhibited the lowest value $\left(69 \mu \mathrm{g} \mathrm{m}^{-3}, 50.14 \mu \mathrm{g} \mathrm{m}^{-3}\right.$, $14.1 \mu \mathrm{g} \mathrm{m}^{-3}$, and $8.0 \mu \mathrm{g} \mathrm{m}^{-3}$ ) on January 26 .

The formation of sulfate is complicated, and it was divided into homogeneous process and heterogeneous reaction. For homogeneous process, it included gas-phase 
Table 2. Air quality in Zhengzhou during the measurement period.

\begin{tabular}{llll}
\hline Date & AQI & $\mathrm{PM}_{2.5}\left(\mu \mathrm{g} \mathrm{m}^{-3}\right)$ & Air quality level $(\mathrm{CMEP})$ \\
\hline $2014 / 1 / 24$ & 245 & 195 & Heavily Polluted \\
$2014 / 1 / 25$ & 179 & 135 & Moderately Polluted \\
$2014 / 1 / 26$ & 69 & 50 & Good \\
$2014 / 1 / 27$ & 115 & 87 & Lightly Polluted \\
$2014 / 1 / 28$ & 133 & 101 & Lightly Polluted \\
$2014 / 1 / 29$ & 182 & 137 & Moderately Polluted \\
$2014 / 1 / 30$ & 243 & 193 & Heavily Polluted \\
$2014 / 1 / 31$ & 314 & 209 & Severely Polluted \\
\hline
\end{tabular}

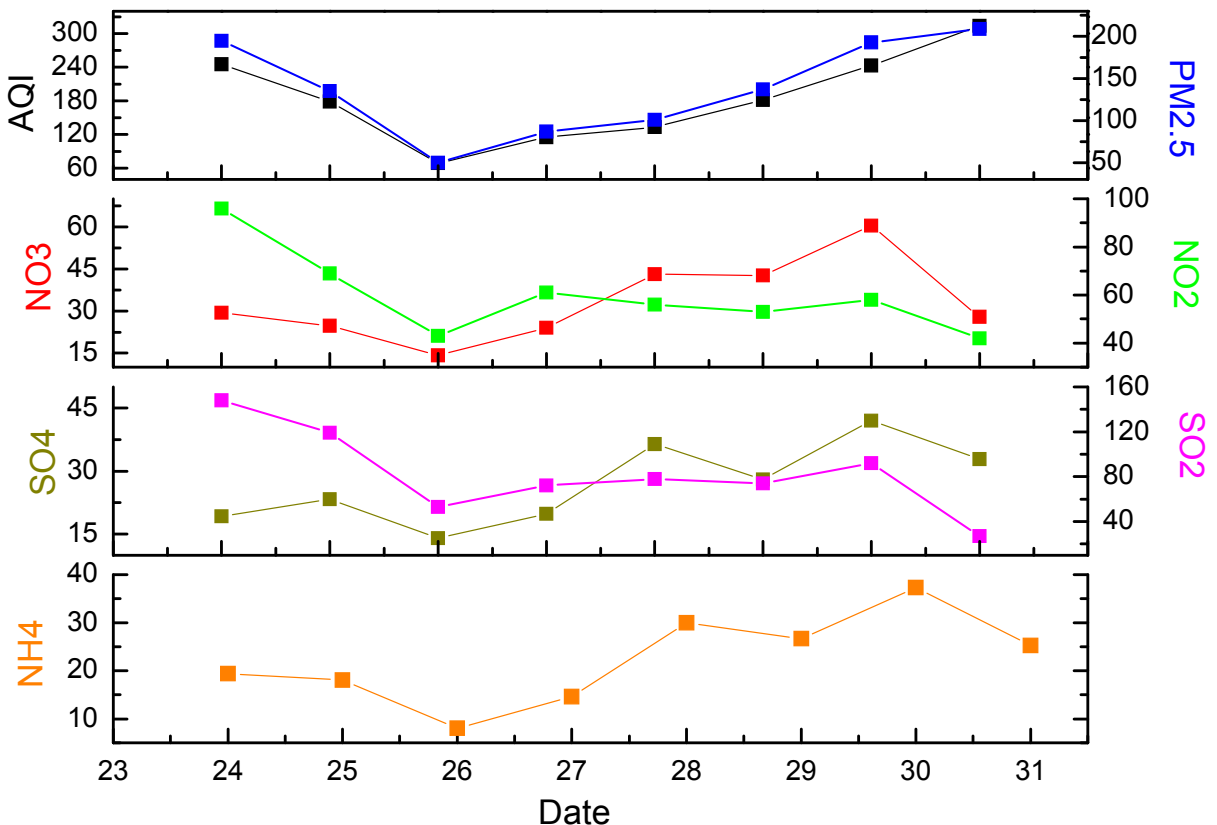

Fig. 3. Daily variability of $\mathrm{PM}_{2.5}, \mathrm{NO}_{2}, \mathrm{SO}_{2}, \mathrm{NO}_{3}{ }^{-}, \mathrm{SO}_{4}{ }^{2-}$, and $\mathrm{NH}_{4}{ }^{+}$concentrations and AQI.

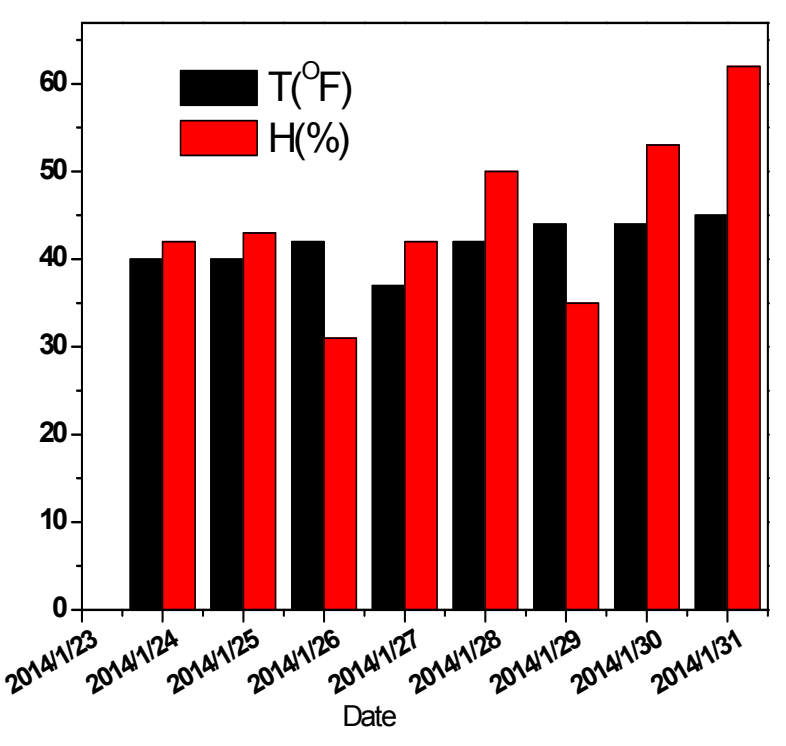

Fig. 4. Daily variability of temperature and humidity.

reactions of $\mathrm{SO}_{2}$ and free radical (OH etc.), and $\mathrm{SO}_{2}$ dissolved in the water to form $\mathrm{H}_{2} \mathrm{SO}_{3}$ and was then oxidized by the oxidant $\left(\mathrm{H}_{2} \mathrm{O}_{2}\right.$ etc. $)$ to sulfate. For heterogeneous processes, it included $\mathrm{SO}_{2}$ reacting with $\mathrm{OH}, \mathrm{O}_{3}$, or $\mathrm{H}_{2} \mathrm{O}_{2}$ to produce sulfate which occurred in the aqueous surface layer preexisting particle. So the homogeneous process maybe show that the sulfate correlated well with $\mathrm{SO}_{2}$. And the heterogeneous reaction will be the main factor if the sulfate is a function of RH (Liang and Jacobson, 1999). That means the heterogeneous conversion rates from $\mathrm{SO}_{2}$ to sulfate was sensitive to humidity (McMurry and Wilson, 1983). Fig. 5 demonstrates that sulfate poorly correlated with $\mathrm{SO}_{2}\left(\mathrm{R}^{2}=0.373\right)$ and the sulfate concentrations decreased with the $\mathrm{RH}$, which suggests that the reduction in sulfate levels in Stage 1 might be from heterogeneous processes. Fig. 6 displays the wind speed at this stage, which suggests the air velocity was not strong. Therefore, the wind direction may have caused the pollutants to rapidly disperse and the haze to clear. The details are provided in Section "Source of Pollution".

Just like the sulfate, nitrate also can form from $\mathrm{NO}_{2}$ through homogeneous reactions between $\mathrm{HNO}_{3}$ and $\mathrm{NH}_{3}$ or heterogeneous reaction of nitrogen species $\left(\mathrm{HNO}_{3}, \mathrm{NO}_{3}\right.$, $\mathrm{N}_{2} \mathrm{O}_{5}$, etc.). The gas-to-particle partitioning of $\mathrm{NH}_{4} \mathrm{NO}_{3}$ is mainly ruled by $\mathrm{RH}$ and temperature. Fig. 5 showed the 

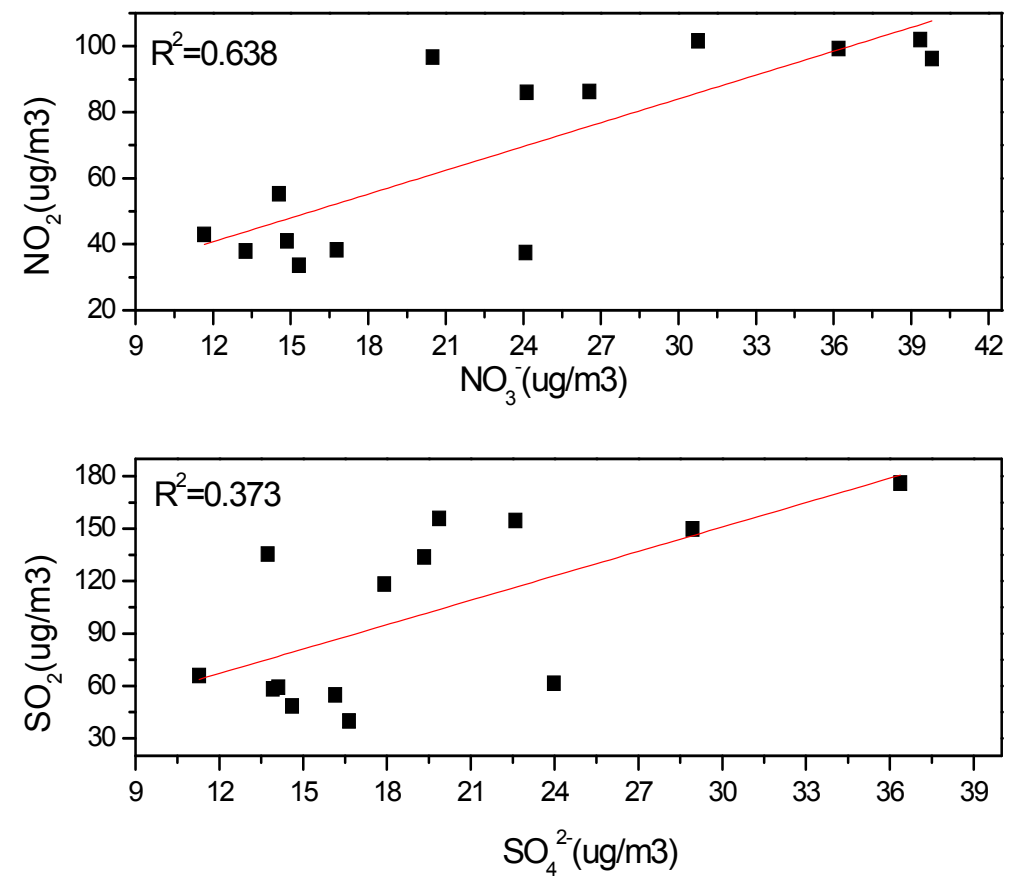

Fig. 5. Scatter plot and linear regression analysis of $\mathrm{NO}_{3}{ }^{-}$and $\mathrm{NO}_{2} ; \mathrm{SO}_{4}{ }^{2-}$ and $\mathrm{SO}_{2}$.

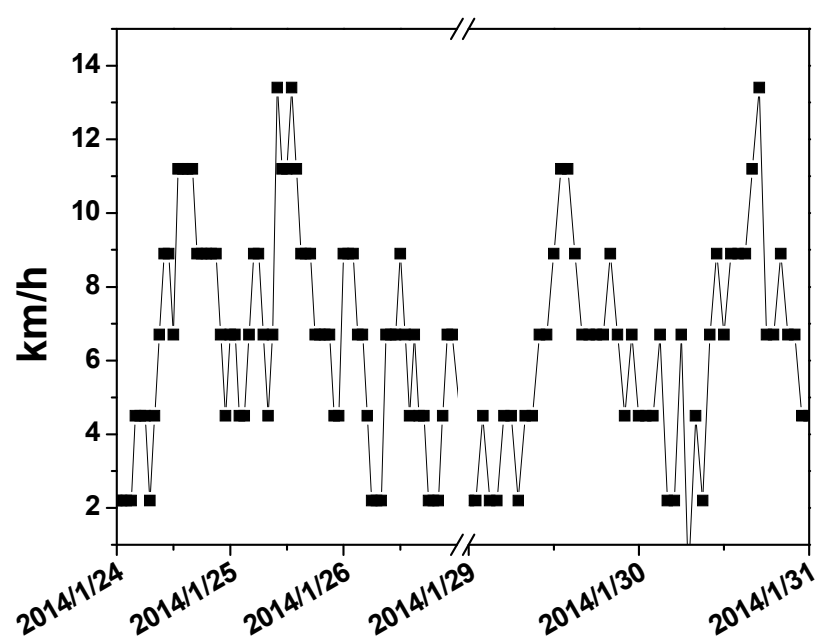

Fig. 6. Time series of wind speed.

nitrate correlated well with $\mathrm{NO}_{2}\left(\mathrm{R}^{2}=0.638\right)$, suggesting that the nitrate concentration was mainly affected by $\mathrm{NO}_{2}$, and the nitrate might form through homogeneous reactions of $\mathrm{NO}_{2}$ with $\mathrm{O}_{3}$ or $\mathrm{OH}$ to form $\mathrm{HNO}_{3}$ in the gas phase during daytime, while forming through heterogeneous reactions during the night due to the meteorology condition, which then reacts with $\mathrm{NH}_{3}$ to form $\mathrm{NH}_{4} \mathrm{NO}_{3}$ through the gas-to-particle partition (Wang et al., 2007). This assumption also supports the relationship between nitration and humidity, and the nitrates increased with the humidity.

Stage 2 (January 26 to the Noon of January 30)

From January 26 to 10:00 a.m. on January 29, the concentration of $\mathrm{PM}_{2.5}, \mathrm{NO}_{2}, \mathrm{SO}_{2}, \mathrm{SO}_{4}{ }^{2-}, \mathrm{NO}_{3}{ }^{-}$, and $\mathrm{NH}_{4}{ }^{+}$ did not significantly increase. Fig. 7 displays the 4-hour averaged time variations of $\mathrm{PM}_{2.5}$ mass concentration, ion concentration, $\mathrm{SO}_{2}$ and $\mathrm{NO}_{2}$ concentrations, and meteorological conditions during the entire measurement period. The ion concentration (sulfate, nitrate, and ammonium) sharply increased, and they increased by $1.86-$, 1.66-, and 1.39-fold on average, changing from 19.77, 32.16 , and $20.73 \mu \mathrm{g} \mathrm{m}^{-3}$ to $56.54,85.62$, and $49.54 \mu \mathrm{g} \mathrm{m}^{-3}$, respectively, from 10:00 a.m. on January 29 to 10:00 a.m. on January 30 during Stage 2 . In this stage, the $\mathrm{PM}_{2.5}$ mass changed marginally from $132.7 \mu \mathrm{g} \mathrm{m}^{-3}$ to $144.3 \mu \mathrm{g} \mathrm{m}^{-3}$. During this time, the RH was only approximately $40-60 \%$, and the temperature was approximately $30-50^{\circ} \mathrm{F}$. Therefore, the hygroscopic growth of particles was not the main reason for the increased particle levels in Stage 2. Moreover, the concentrations of ions were higher than those in two massive firework burning events (Section "Stage 3 (from the afternoon of January 30 to January 31 )"); thus, fireworks were also not the main reason.

The sulfur oxidation ratio $\left(\mathrm{SOR}, \mathrm{SOR}=\mathrm{n}-\mathrm{SO}_{4}{ }^{2-} /\left(\mathrm{n}-\mathrm{SO}_{4}{ }^{2-}\right.\right.$ $\left.+\mathrm{n}-\mathrm{SO}_{2}\right)$ ) and the nitrogen oxidation ratio $(\mathrm{NOR}, \mathrm{NOR}=$ $\left.\mathrm{n}-\mathrm{NO}_{3}{ }^{-} /\left(\mathrm{n}-\mathrm{NO}_{3}{ }^{-}+\mathrm{n}-\mathrm{NO}_{2}\right)\right)$ are the main parameters. They can be used as indications of the secondary formation.

According to Seinfeld (1986), the gas-phase oxidation of $\mathrm{SO}_{2}$ to $\mathrm{SO}_{4}{ }^{2-}$ by an $\mathrm{OH}$ radical is a strong function of temperature. Fig. 8 indicates that the SOR was correlated with $\mathrm{SO}_{4}{ }^{2-}\left(\mathrm{R}^{2}=0.45\right)$, suggesting the formation of sulfate in Stage 2 could not be mainly from gas-phase oxidation and the heterogeneous process. Thus, sulfur oxidation might not be the main process. Therefore, transportation may be the other reason for the increasing trend.

A pronounced increase in the concentration of nitrate was observed. Moreover, daily cycles were found for this concentration, with peak concentration in the morning, followed by decreases in the afternoon, which is similar to 


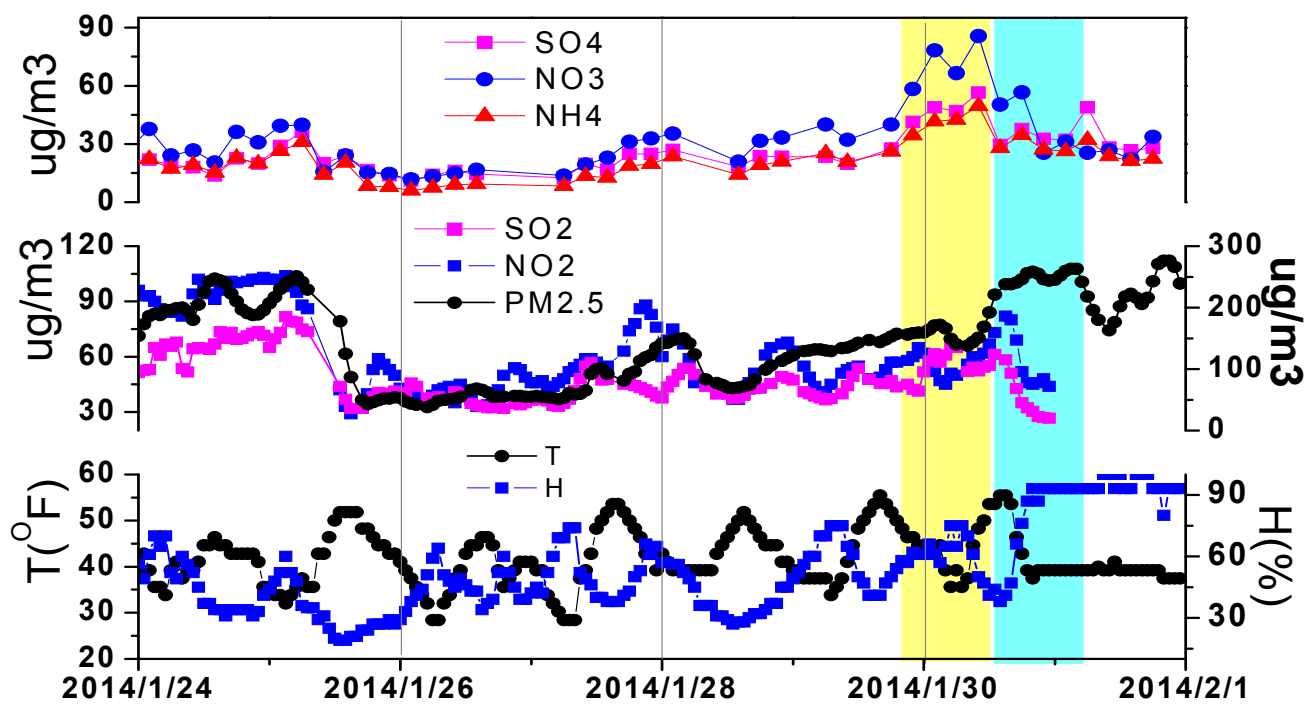

Fig. 7. Time series of meteorological parameters and pollutant concentration measured during measurement period.

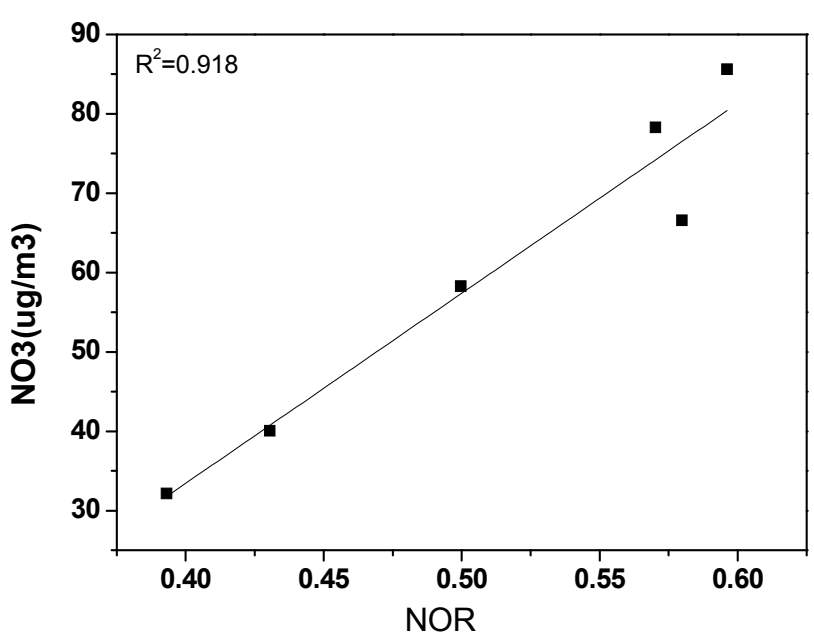

(a)

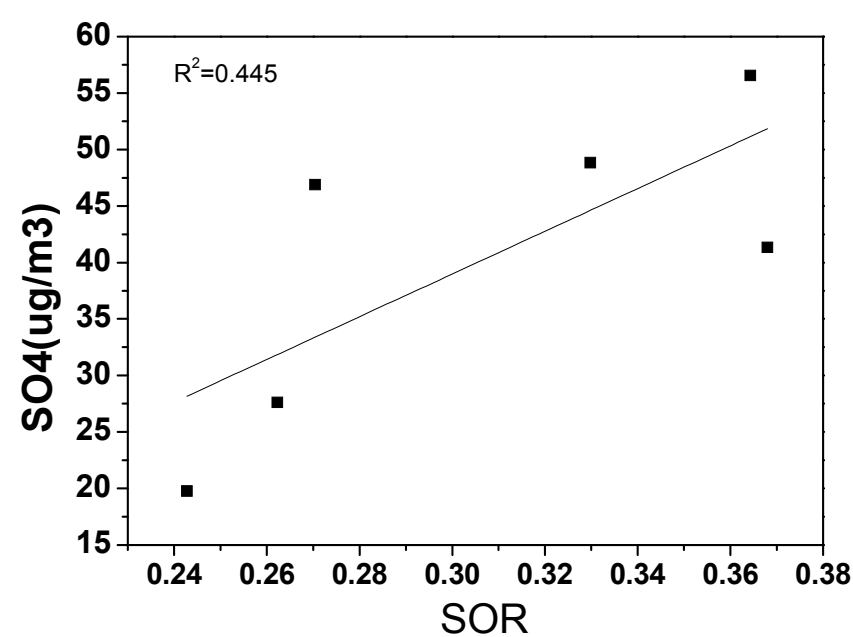

(b)

Fig. 8. Scatterplot and linear regression analysis of (a) $\mathrm{NO}_{3}{ }^{-}$and NOR; (b) $\mathrm{SO}_{4}{ }^{2-}$ and $\mathrm{SOR}$.

the trend for sulfate. This is because the nitrate concentration is driven by $\mathrm{HNO}_{3}$ production related to gasto-particle partitioning to form ammonium nitrate, which is more prevalent at lower temperature and higher relative humidity. However, the $\mathrm{NO}_{2}$ concentration increased slowly, and the nitrate concentration reached a sharp peak, indicating that regional transportation may have a critical role in controlling nitrate concentrations (Zhang et al., 2005). Fig. 8 reveals that the NOR correlated well with nitrate $\left(\mathrm{R}^{2}=0.91\right)$, which suggests that nitrate was formed through homogeneous reactions of $\mathrm{NO}_{2}$ with $\mathrm{O}_{3}$ or $\mathrm{OH}$ to form $\mathrm{HNO}_{3}$ in the gas phase, which then reacts with $\mathrm{NH}_{3}$ to form $\mathrm{NH}_{4} \mathrm{NO}_{3}$ (Wang et al., 2007). The NOR levels were higher than SOR levels, which was in agreement with the formation rate of nitrate being approximately ten times higher than that of sulfate (Hewitt, 2001).

Ammonium showed a trend similar to that for sulfate and nitrate, which indicates that it is present mainly in the form of ammonium sulfate and ammonium nitrate.
Stage 3 (from the Afternoon of January 30 to January 31)

In the measurement period, Chinese New Year occurred on January 31. A different trend was found for pollution on January 30 and January 31. On Chinese New Year's Eve, two massive firework burning events occur almost in the evening (at approximately 5:00-8:00 p.m., for the family reunion dinner), and at midnight (around 12:00-3:00 a.m., to celebrate the New Year). Fig. 7 reveals that the firework event had an obvious effect on fine particle concentrations. $\mathrm{PM}_{2.5}$ exhibited its maximum concentration for those two episodes, which was $258 \mu \mathrm{g} \mathrm{m}^{-3}$ at 8:00 p.m. on January 30 and $263 \mu \mathrm{g} \mathrm{m}^{-3}$ at 3:00 a.m. on January 31 . The average concentration of $\mathrm{PM}_{2.5}$ increased 0.8 -fold, changing from approximately $140 \mu \mathrm{g} \mathrm{m}^{-3}$ to $260 \mu \mathrm{g} \mathrm{m}^{-3}$. The concentrations of sulfate, nitrate, and ammonium were high from 6:00 p.m. on January 30 to $6: 00$ a.m. on January 31 . The concentrations of sulfate, nitrate, and ammonium were $37.62 \mu \mathrm{g} \mathrm{m}^{-3}$, $56.63 \mu \mathrm{g} \mathrm{m}^{-3}$, and $34.63 \mu \mathrm{g} \mathrm{m}^{-3}$ at 6:00 p.m. on January 30 , they were $32.14 \mu \mathrm{g} \mathrm{m}^{-3}, 31.14 \mu \mathrm{g} \mathrm{m}^{-3}$, and $26.35 \mu \mathrm{g} \mathrm{m}^{-3}$ 
at 2:00 a.m. on January 31 , and they were $48.86 \mu \mathrm{g} \mathrm{m}^{-3}$, $25.49 \mu \mathrm{g} \mathrm{m}^{-3}$, and $32.09 \mu \mathrm{g} \mathrm{m}^{-3}$ at $6: 00$ a.m. on January 31 , respectively.

Fig. 7 suggests that the $\mathrm{PM}_{2.5}$ mass fraction was very high, but the ion (sulfate, nitrate, and ammonium) mass fractions were lower during the firework events. Therefore, one reason is possible that the mass fractions of the carbon compounds, $\mathrm{Cl}$, and $\mathrm{K}$ were very high (Wang et al., 2007), and the other reason may be the hygroscopic growth of particles during this period. The RH was approximately $66 \%$ at 5:00 p.m., and it increased to $90 \%$ at 8:00 p.m. (it began to rain), and this level lasted until 6:00 a.m. on January 31 . The concentrations of sulfate, nitrate, and ammonium began to decrease during this measurement period and may have been a result of aerosol wet scavenging (Sun et al., 2011). Zhang et al. (2015) also revealed that the burning of fireworks emits a large fraction of aerosol particles in the size range of $1-2.5 \mu \mathrm{m}$, and volatile organic compounds (VOCs) play a role in the aerosol phase during firework displays. Wang et al. (2007) showed the ions (sulfate, nitrate, ammonium) would increase in the firework times. However, compared with that in Stage 2 , the concentrations of ions in the two massive firework burning events were lower, which means that aerosol wet scavenging had a greater effect on ions than did fireworks during this period, while the hygroscopic growth of particles maybe affected the concentration of $\mathrm{PM}_{2.5}$ during this period.

The fireworks could be one factor for the pollution during the firework events (Wang et al., 2007; Zhang et al., 2015). But in our paper, aerosol wet scavenging and the hygroscopic growth of particles had a great effect on pollution.

\section{Cation and Anion Balance}

To determine the reasons for the formation of pollution in different stages, we also studied the cation and anion balance in $\mathrm{PM}_{2.5}$.

The calculations of the equivalence of cations and anions are obtained through the following equations:

Cation equivalence $=\mathrm{NH}_{4}^{+} / 18.04$

Anion equivalence $=\mathrm{NO}_{3}{ }^{-} / 62.005+2 \times \mathrm{SO}_{4}{ }^{2-} / 96.06$

Fig. 9 reveals a high correlation between the calculated equivalence of cations and anions, with $\mathrm{R}^{2}>0.94$. This finding indicates that $\mathrm{NH}_{4}^{+}$exists in the air with ammonium sulfate and ammonium nitrate, and the slope indicates that the air was neutralized during the measurement period in Zhengzhou.

During the measurement period (January 24-31), the nitrate to sulfate ratios were approximately $1-2$, which indicated that nitrate was more likely to be formed than sulfate. This phenomenon is similar to that observed in particle studies in Taiwan and Beijing. The most abundant anions of $\mathrm{PM}_{2.5}$ were $\mathrm{Cl}^{-}$, nitrate (avg.: 5.49), and sulfate (avg.: 2.03). Tsai et al. (2012) discovered that the mass fraction of nitrate was higher than sulfate during Taiwan's
Lantern Festival, and Jiang et al. (2015) reported that nitrate levels increased faster than sulfate levels during a firework display in Beijing.

The mass ratio of nitrate to sulfate has been employed as an indicator of the relative importance of stationary versus mobile sources of sulfur and nitrogen in the atmosphere (Arimoto et al., 1996; Yao et al., 2002; Wang et al., 2006). In China, the ratios are different in cities in different seasons. Lai et al. (2007) reported a ratio of $0.36-0.68$ in $\mathrm{PM}_{2.5}$ at eight sites in winter. Fig. 10 displays the time series of the mass ratio of nitrate to sulfate. In this study, nitrate to sulfate ratios were in the range of $0.52-1.72$, with a mean of 1.29. These ratios were much higher than that in Beijing (0.71) and Shanghai (0.64) (Wang et al., 2005). Excluding the firework period (10:00 p.m. on January 30 to $6: 00$ p.m. on January 31 ), nitrate to sulfate ratios were in the range of $0.77-1.72$, with a mean of 1.33 , which were still higher than that in Beijing. During the heavy firework period, the ratios decreased rapidly from approximately 1.6 to 0.6 , which is similar to that reported by Tian et al. (2014), who revealed that the mass ratios of nitrate to sulfate during the heavy firework period were lower than those during the light firework period. This suggests that although stationary sources, such as power plants and other industrial sources of emission, are crucial contributors, mobile sources of emissions should not be neglected in winter in Zhengzhou.

\section{Source of Pollution}

For Stage 1, Fig. 11 reveals that the wind from the east of Zhengzhou was clear air, which resulted in the rapid dispersal of pollutants and the clearing of haze. Duo (2016) studied the transportation of Zhengzhou and also revealed the wind from the east could decrease the concentration of the pollution.

For Stage 2, transport was one of the main sources of pollution, in particular from 10:00 p.m. (14:00 UTC) on January 29 to 2:00 p.m. (06:00 UTC) on January 30, when the concentrations of sulfate, nitrate, ammonium, $\mathrm{SO}_{2}$, and $\mathrm{NO}_{2}$ increased rapidly. To study the regional transport of $\mathrm{PM}_{2.5}$ from neighboring sources, air mass trajectories were downloaded from ARL's website (https://ready.arl.noaa.gov/ hypub-bin/trajtype.pl) to study the sources of pollution. During the measurement period, the air mass trajectories revealed that air mass at $500 \mathrm{~m}$ was mainly from the northwest, and the pollutant concentration increased. The air mass originated from the northwest and traveled across Shanxi Province and Shaanxi Province, and might contain a large amount of pollutants from the northwestern polluted areas. Consequently, pollutant concentrations may have increased. Huang et al. (2017) also revealed that $\mathrm{PM}_{2.5}$ concentrations in Shijiazhuang, which originated from Inner Mongolia and passed over Shanxi Province to arrive at the sampling location, resulted in the highest $\mathrm{PM}_{2.5}$ value $\left(178.9 \mu \mathrm{g} \mathrm{m}^{-3}\right)$. Fig. 6 showed the ground wind speed was about 5-7 $\mathrm{km} \mathrm{h}^{-1}$ which came from the northwest from 10:00 p.m. on January 29 to 2:00 a.m. on January 30 . The pollutions increased. And then the wind speed began to decrease to $0-4 \mathrm{~km} \mathrm{~h}^{-1}$ which made the pollutions began 
(a)
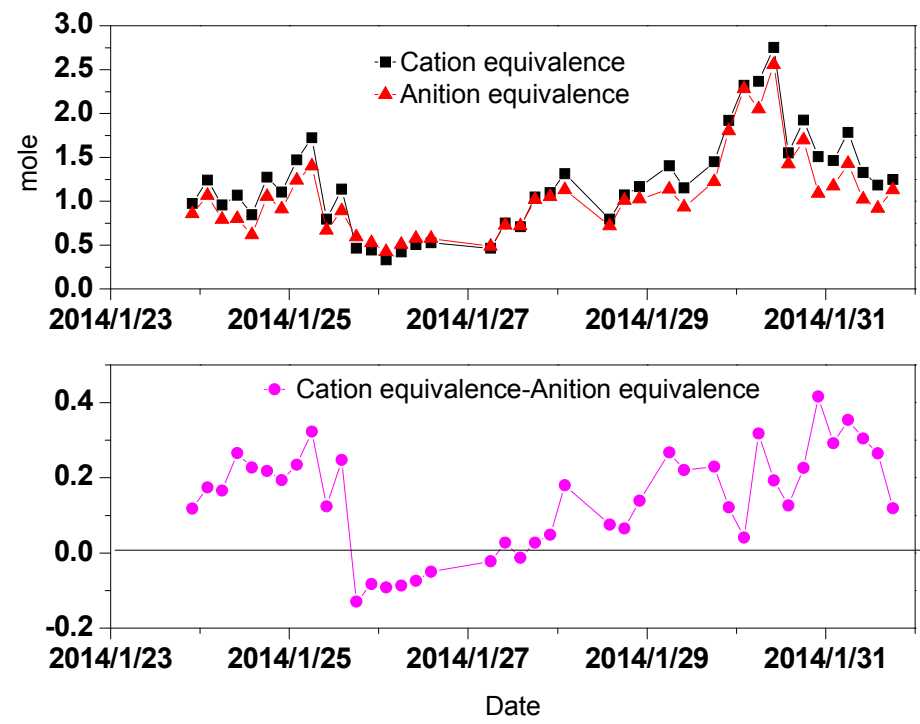

(b)

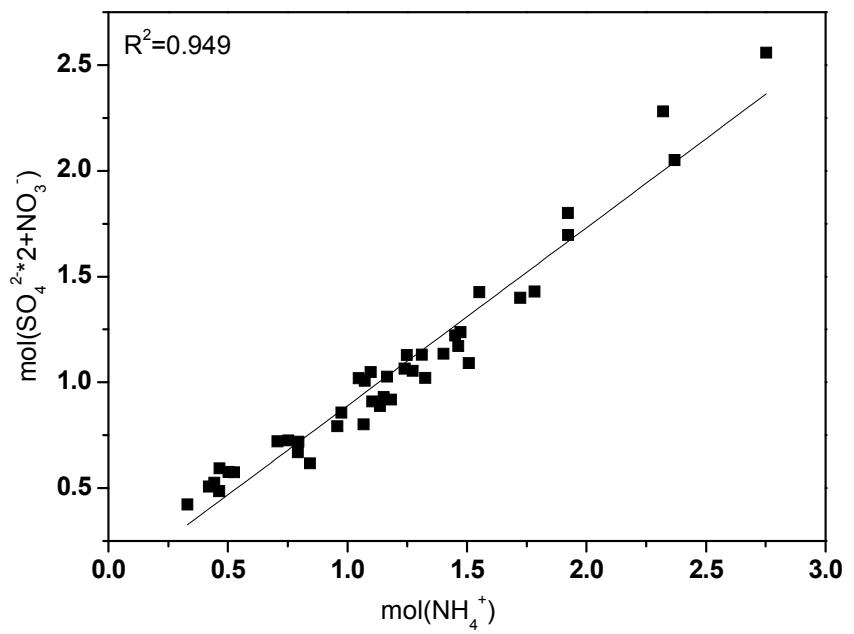

Fig. 9. (a) Time series of cation and anion levels and the acidity in $\mathrm{PM}_{2.5}$ and (b) Correlation between cations and anions.

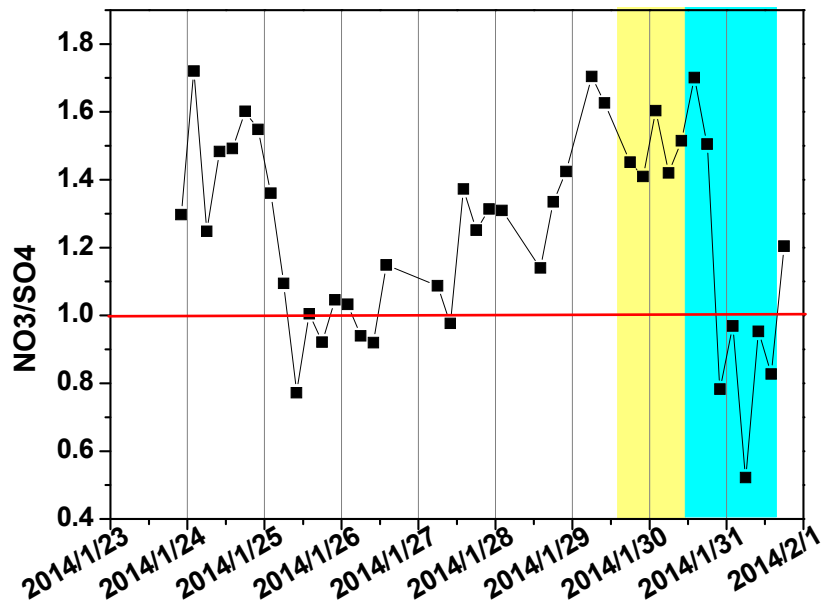

Fig. 10. Time series of the mass ratio of nitrate/sulfate.

to assemble. The wind increased to about $7-9 \mathrm{~km} \mathrm{~h}^{-1}$, the region transport from 10:00 a.m. on January 30 to 2:00 p.m. (6:00 a.m. UTC) on January 30.
For Stage 3, pollution particles dispersed only after 6:00 p.m. (10:00 a.m. UTC) on January 30, when the wind direction changed from northwest to south and the wind speed decreased. Subsequently, Chinese New Year followed, and the fireworks display occurred, resulting in increased emissions of sulfur compounds and nitrogenous compounds. However, from Fig. 11, the effect of transportation from the northwest was greater than the local source of pollution.

Therefore, in Zhengzhou, the pollution from east clears and the pollution from the northwest increases which was similar with the result of Hebei (Huang et al. 2017). The pollutions would be easy to assemble in the stable meteorological conditions.

\section{CONCLUSION}

Inorganic compounds in the $\mathrm{PM}_{2.5}$ were measured using FTIR from January 24 to January 31, 2014, in Zhengzhou. By combining the data on gases $\left(\mathrm{NO}_{2}\right.$ and $\left.\mathrm{SO}_{2}\right)$, particle mass concentration $\left(\mathrm{PM}_{2.5}\right)$, and meteorological parameters, the daily variations and time series of the pollution were 

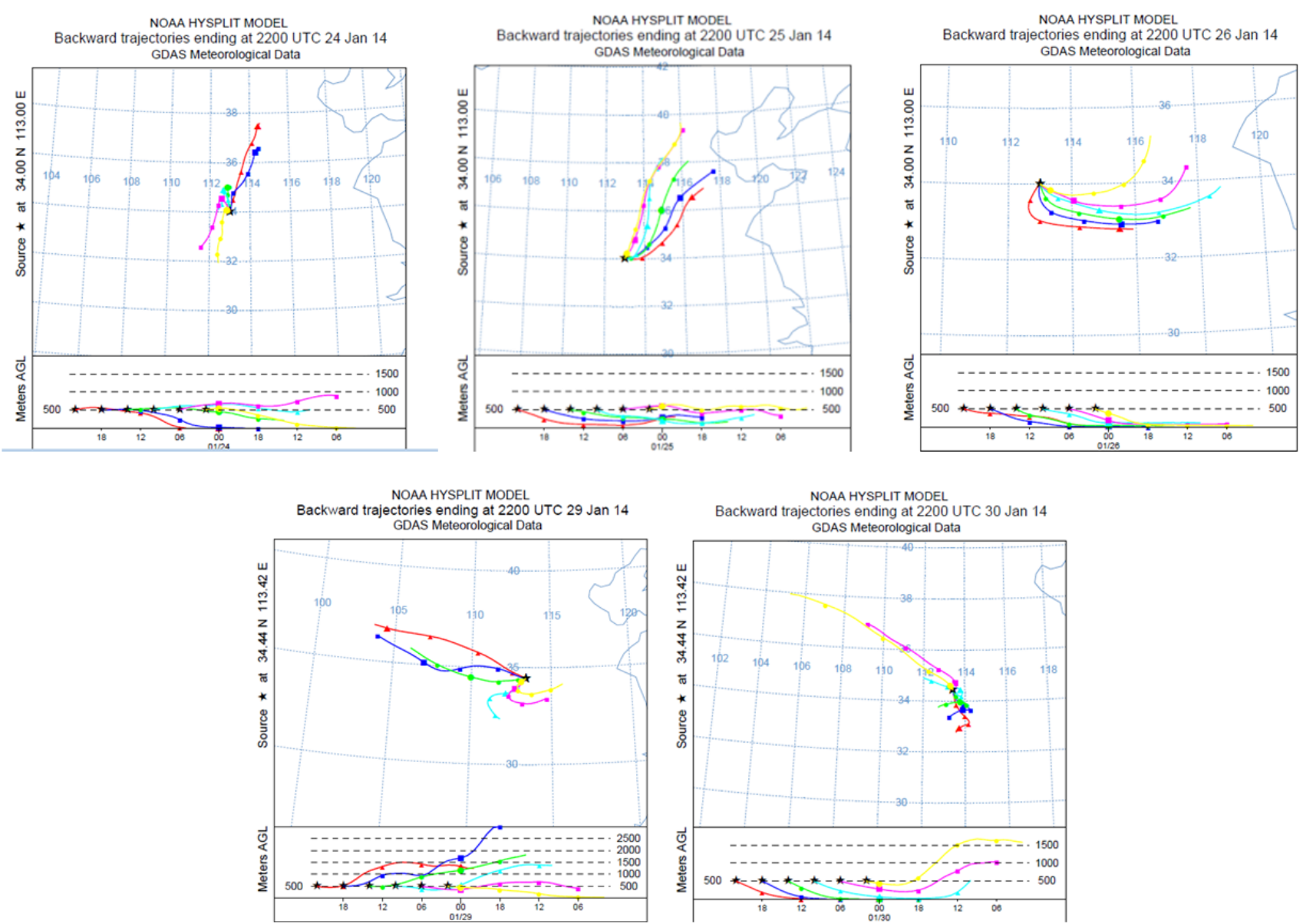

Fig. 11. Backward trajectory determined by the National Oceanic and Atmospheric Administration Hybrid Single-Particle Lagrangian Integrated Trajectory (HYSPLIT) model.

analyzed, and the measurement period was divided into three stages according to the trends. Pollution levels were low during Stage 1 (January 24-26). The $\mathrm{NO}_{3}{ }^{-}$concentration correlated well with the $\mathrm{NO}_{2}$ concentration $\left(\mathrm{R}^{2}=0.89\right)$, suggesting that the former was mainly affected by $\mathrm{NO}_{2}$. The $\mathrm{SO}_{4}{ }^{2-}$ concentration also correlated well with the humidity $\left(\mathrm{R}^{2}=0.72\right)$ but poorly with the $\mathrm{SO}_{2}$ concentration $\left(\mathrm{R}^{2}=0.054\right)$, suggesting that the formation of sulfate in Stage 1 may have resulted mainly from heterogeneous processes. Wind from the east of Zhengzhou was one main reason that pollutants rapidly dispersed and the haze cleared. In Stage 2 (January 26 to noon on January 30), the SOR correlated poorly with the $\mathrm{SO}_{4}{ }^{2-}$ concentration $\left(\mathrm{R}^{2}=\right.$ $0.45)$, indicating that transportation was the primary cause of the high sulfate concentration, and the NOR correlated well with the $\mathrm{NO}_{3}{ }^{-}$concentration $\left(\mathrm{R}^{2}=0.91\right)$, suggesting that nitrate was formed through homogeneous gas-phase reactions of $\mathrm{NO}_{2}$ with $\mathrm{OH}$ or $\mathrm{O}_{3}$, becoming $\mathrm{HNO}_{3}$ in the $\mathrm{PM}_{2.5}$. In Stage 3 (the afternoon of January 30 to January 31 ), the average concentration of the $\mathrm{PM}_{2.5}$ increased from approximately $140 \mu \mathrm{g} \mathrm{m}^{-3}$ to $260 \mu \mathrm{g} \mathrm{m}^{-3}$. The high levels of $\mathrm{PM}_{2.5}$ during this stage may have been caused primarily by the hygroscopic growth of particles. The concentrations of sulfate, nitrate, and ammonium decreased from $37.62 \mu \mathrm{g} \mathrm{m}^{-3}$, $56.63 \mu \mathrm{g} \mathrm{m}^{-3}$, and $34.63 \mu \mathrm{g} \mathrm{m}^{-3}$ to $32.14 \mu \mathrm{g} \mathrm{m}^{-3}, 31.14 \mu \mathrm{g} \mathrm{m}^{-3}$, and $26.35 \mu \mathrm{g} \mathrm{m}^{-3}$, respectively. And the aerosol wet scavenging maybe be the reason. The calculated equivalence of the cations (ammonium) correlated well with that of the anions (sulfate and nitrate) $\left(\mathrm{R}^{2}=0.94\right)$, which indicates that $\mathrm{NH}_{4}^{+}$was present in the air along with ammonium sulfate and ammonium nitrate, and the slope suggests that the air in Zhengzhou was neutralized during the measurement period. The nitrate-to-sulfate ratios were approximately 12 , suggesting that although stationary sources, such as power plants and other sources of industrial emissions, are critical contributors, mobile sources of air pollution should not be neglected during winter in this area; these ratios were also low during the heavy-fireworks period. Backward trajectory analysis indicates that whereas pollution from the east dissipated in Zhengzhou, emissions from the northwest increased.

\section{ACKNOWLEDGMENTS}

This work was supported by the National Natural Science Foundation of China (No. 91544218 and No. 41375027) and The Science and Technological Fund of Anhui Province for Outstanding Youth (No. 1808085J19). We thank the Department of Environmental Protection of Henan Province for use of their location for sampling. 


\section{REFERENCE}

Allen, D.T., Palen, E.J. and Haimov, M.I. (1994). Fourier transform infrared spectroscopy of aerosol collected in a low pressure impactor (LPI/FTIR): Method of development and field calibration. Aerosol Sci. Technol. 21: $325-342$.

Arimoto, R., Duce, R.A., Savoie, D.L. Prospero, J.M., Talbot, R., Cullen, J.D., Tomza, U., Lewis, N.F. and Ray, B.J. (1996). Relationships among aerosol constituents from Asia and the North Pacific during PEM-West A. $J$. Geophys. Res. 101: 2011-2023.

Bardouki, H., Liakakou, H., Economou, C., Scaire, J., Smolik, J., Zdimal, V., Eleftheriadis, K., Lazaridis, M., Dye, C. and Mihalopoulos, N. (2003). Chemical composition of sizeresolved atmospheric aerosols in the eastern Mediterranean during summer and winter. Atmos. Environ. 37: 195-208.

Bishop, J.L., Banin, A., Mancinelli, R.L. and Klovstad, M.R. (2002). Detection of soluble and fixed $\mathrm{NH}_{4}{ }^{+}$in clay minerals by DTA and IR reflectance spectroscopy: a potential tool for planetary surface exploration. Planet. Space Sci. 50: 11-19.

Chan, C.K. and Yao, X. (2008). Air pollution in mega cities in China. Atmos. Environ. 42: 1-42.

Chang, Y.H., Deng, C., Cao, F., Cao, C., Zou, Z., Liu, S. D., Lee, X. H., Li, J., Zhang, G. and Zhang, Y.L. (2017). Assessment of carbonaceous aerosols in Shanghai, China: Long-term evolution, seasonal variations and meteorological effects. Atmos. Chem. Phys. 17: 99459964.

Coury, C. and Dillner, A.M. (2008). A method to quantify organic functional groups and inorganic compounds in ambient aerosols using attenuated total reflectance FTIR spectroscopy and multivariate chemometric techniques. Atmos. Environ. 42: 5923-5932.

Duo, K.Z. (2016). Formation mechanism and control strategies of atmospheric haze: Specialized research results of atmospheric haze in Henan province. China Environmental Science Press, Beijing. (in Chinese)

Feng, J.L., Yu, H., Su, X.F., Liu, S.H., Li, Y., Pan, Y.P. and Sun, J.H. (2016). Chemical composition and source apportionment of $\mathrm{PM}_{2.5}$ during Chinese Spring Festival at Xinxiang, a heavily polluted city in North, China: Fireworks and health risks. Atmos. Res. 182: 176-188.

Geng, N.B., Wang J., Xu Y.F., Zhang W.D., Chen C. and Zhang, R.Q. (2013). $\mathrm{PM}_{2.5}$ in an industrial district of Zhengzhou, China: Chemical composition and source apportionment. Particuology.11:99-109.

Godri, K.J., Green, D.C., Fuller, G.W., Dall'Osto, M., Beddows, D.C., Kelly, F.J., Harrison, R.M. and Mudway, I.S. (2010). Particulate oxidative burden associated with firework activity. Environ. Sci. Technol. 44: 8295-8301.

He, K., Yang, F., Ma, Y., Zhang, Q., Yao, X., Chan, C., Cadle, S., Chan, T. and Mulawa, P. (2001). The characteristics of $\mathrm{PM}_{2.5}$ in Beijing, China. Atmos. Environ. 35: 4959-4970.

Hewitt, C.N. (2001). The atmospheric chemistry of sulfur and nitrogen in power station plumes. Atmos. Environ. 35: $1155-1170$.

Hug, S.J. (1997). In situ Fourier transform infrared measurements of sulfate adsorption on hematite in aqueous solutions. J. Colloid Interface Sci. 188: 415422.

Huang, X.J., Liu, Z.R., Liu, J.Y., Hu, B., Wen, T.X., Tang, G.Q., Zhang, J.K., Wu, F.K., Ji, D.S., Wang, L.L. and Wang, Y.S. (2017). Chemical characterization and synergetic source apportionment of $\mathrm{PM}_{2.5}$ at multiple sites in the Beijing-Tianjin-Hebei region, China. Atmos. Chem. Phys. Discuss. 231: 871-881.

Jiang, N., Guo, Y., Wang, Q., Kang, P.R., Zhang R.Q. and Tang, X.Y. (2017). Chemical composition characteristics of $\mathrm{PM}_{2.5}$ in three cities in Henan, Central China. Aerosol Air Qual. Res. 17: 2367-2380.

Jiang, Q., Sun, Y.L., Wang, Z.F. and Yin, Y. (2015). Aerosol composition and sources during the Chinese Spring Festival: Fireworks, secondary aerosol, and holiday effects. Atmos. Chem. Phys. 15: 6023-6034.

Kadir, M.F.Z., Aspanut, Z., Majid, S.R. and Arof, A.K. (2011). FTIR studies of plasticized poly(vinyl alcohol)chitosan blend doped with $\mathrm{NH}_{4} \mathrm{NO}_{3}$ polymer electrolyte membrane. Spectrochim. Acta, Part A 78: 1068-1074.

Kong, S.F., Li, L., Li, X.X., Yin, Y., Chen, K., Liu, D.T., Yuan, L., Zhang, Y.J., Shan, Y.P. and Ji, Y.Q. (2015). The impacts of firework burning at the Chinese Spring Festival on air quality: Insights of tracers, source evolution and aging processes. Atmos. Chem. Phys. 15: 2167-2184.

Lai, S.C, Zou, S.C., Cao, J.J., Lee, S.C. and Ho, K.F. (2007). Characterizing ionic species in $\mathrm{PM}_{2.5}$ and $\mathrm{PM}_{10}$ in four Pearl River Delta cities, South China. J. Environ. Sci. 19: 939-947.

Li, H.Y., Zhang, Q., Zhang, Q., Chen, C.R., Wang, L.T., Wei, Z., Zhou, S., Parworth, C., Zheng, B., Canonaco, F., Prevot, A.S.H., Chen, P., Zhang, H.L., Wallington, T.J. and He, K.B. (2017). Wintertime aerosol chemistry and haze evolution in an extremely polluted city of the North China Plain: Significant contribution from coal and biomass combustion. Atmos. Chem. Phys. 17: 47514768

Liang, J.Y. and Jacobson, M.Z. (1999). A study of sulfur dioxide oxidation pathways over a range of liquid water contents, PHs and temperature. J. Geophys. Res. 104: 13749-13769.

Liao, X.N., Zhang, X.L., Wang, Y.C., Liu, W.D., Du, J. and Zhao, L.H. (2014). Comparative analysis on meteorological condition for persistent haze cases in summer and winter in Beijing. J. Environ. Sci.-China 35: 2031-2044.

Liu, J.H., Zhang, Y.H., Wang, L.Y. and Wei, Z.F. (2005). Drawing out the structural information of the first layer of hydrated ions: ATR-FTIR spectroscopic studies on aqueous $\mathrm{NH}_{4} \mathrm{NO}_{3}, \mathrm{NaNO}_{3}$, and $\mathrm{Mg}\left(\mathrm{NO}_{3}\right)_{2}$ solutions. Spectrochim. Acta, Part A 6: 1893-899.

Liu, N., Wei, X.L., Gao, M.G. and Xu, L. (2015). A Quantitative analysis method of water-soluble inorganic ions with ATR-FTIR spectroscopy. Spectrosc. Spectral 
Anal. 35: 3364-3368. (in Chinese)

Maria, S.F., Russell, L.M., Turpin, B.L. and Porcja, R.J. (2002). FTIR measurements of functional groups and organic mass in aerosol samples over the Caribbean. Atmos. Environ. 36: 5185-5196.

McMurry, P.H. and Wilson, J.C. (1983). Droplet phase (Heterogeneous) and gas phase (homogeneous) contributions to secondary ambient aerosol formation as functions of relative humidity. J. Geophys. Res. 88: 5101-5108.

Peak, D., Ford, R.G. and Sparks, D. (1999). An in situ ATR-FTIR investigation of sulfate bonding mechanisms on goethite. J. Colloid Interface Sci. 218: 289-299.

Pope, C.A. and Dockery, D.W. (2006). Health effects of fine particulate air pollution: Lines that connect. J. Air Waste Manage. Assoc. 56: 709-742.

Reff, A., Turpin, B.J., Porcja, R.J., Giovenntti, R., Cui, W., Weisel, C.P., Zhang, J., Kwon, J., Alimokhtari, S., Morandi, M., Stock, T., Maberti, S., Colome, S., Winer, A., Shendell, d., Jones, J. and Farrar, C. (2005). Functional group characterization of indoor, outdoor, and personal $\mathrm{PM}_{2.5}$ results from RIOPA. Indoor Air 15: 53-61.

Seinfeld, J.H. (1986). Atmospheric chemistry and physics of air pollution. Wiley, New York, P348.

Shang, X.N., Lee, M., Meng, F., Wang, S.H., Suh, I., Kim, D., Jeon, K., Wang, X.Z., Zhao, Y.X. and Zhang, K. (2018). Characteristics and source apportionment of fine haze aerosol in Beijing during the winter of 2013. Atmos. Chem. Phys. 18: 2573-2584.

Steven, F.M., Lynn, M.R., Barbara, J.T. and Robert, J.P. (2002). FTIR measurements of functional groups and organic mass in aerosol samples over the Caribbean. Atmos. Environ. 36: 5185-5196.

Sun, Y.L., Jiang, Q., Wang, Z.F., Fu, P.Q., Li, J., Yang, T. and Yin, Y. (2014). Investigation of the sources and evolution processes of severe haze pollution in Beijing in January 2013. J. Geophys. Res. 119: 4380-4398.

Sun, Y.L., Zhang, Q., Schwab, J.J., Chen, W.N., Bae, M.S., Lin, Y.C., Hung, H.M. and Demerjian, K.L. (2011). A case study of aerosol processing and evolution in summer in New York City. Atmos. Chem. Phys. 11: 25751-25784.

Tai, A.P.K., Mickley, L.J., Jacob, D.J., Leibensperger, E.M., Zhang, L., Fisher, J.A. and Pye, H.O.T. (2012). Meteorological modes of variability for fine particulate matter $\left(\mathrm{PM}_{2.5}\right)$ air quality in the United States: Implications for $\mathrm{PM}_{2.5}$ sensitivity to climate change. Atmos. Chem. Phys. 12: 3131-3145.

Tao, J., Zhang, L.M., Cao, J.J. and Zhang, R.J. (2017). A review of current knowledge concerning $\mathrm{PM}_{2.5}$ chemical composition, aerosol optical properties, and their relationships across China. Atmos. Chem. Phys. 17: 9485-9518.

Tian, M., Wang, H.B., Chen, Y., Yang, F.M., Zhang, X.H., Zou, Q., Zhang, R.Q., Ma, Y.L. and He, K.B. (2016). Characteristics of aerosol pollution during heavy haze events in Suzhou, China. Atmos. Chem. Phys. 16: 73577371.
Tian, Y.Z., Wang, J., Peng, X., Shi, G.L. and Feng, Y.C. (2014). Estimation of the direct and indirect impacts of fireworks on the physicochemical characteristics of atmospheric $\mathrm{PM}_{10}$ and $\mathrm{PM}_{2.5}$. Atmos. Chem. Phys. 14: 9469-9479.

Tie, X.X. and Cao, J.J. (2009). Aerosol pollution in China: Present and future impact on environment. Particuology 7: 426-431.

Tsai, H.H., Chien, L.H., Yuan, C.S., Lin, Y.C., Jen, Y.H. and Ie, I.R. (2012). Influences of fireworks on chemical characteristics of atmospheric fine and coarse particles during Taiwan's Lantern Festival. Atmos. Environ. 62: 256-264.

Tsai, Y.I. and Kuo, S.C. (2006). Development of diffuse reflectance infrared Fourier transform spectroscopy for the rapid characterization of aerosols. Atmos. Environ. 40: 1781-1793.

Wang, J., Wang, S., Jiang, J., Ding, A., Zheng, M., Zhao, B., Wong, D.C., Zhou, W., Zheng, G., Wang, L., Pleim, J.E. and Hao, J. (2014). Impact of aerosol-meteorology interactions on fine particle pollution during China's severe haze episode in January 2013. Environ. Res. Lett. 9: 094002.

Wang, J., Li, X., Zhang, W., Jiang, N., Zhang, R. and Tang, X. (2016). Secondary $\mathrm{PM}_{2.5}$ in Zhengzhou, China: Chemical species based on three years of observations. Aerosol Air Qual. Res. 16: 91-104.

Wang, S., Yu, S.C., Li, P.F., Wang, L.Q., K., Liu, W.P., Yan, R.C. and Zheng, X.J. (2017). A study of characteristics and origins of haze pollution in Zhengzhou, China, based on observations and hybrid receptor models. Aerosol Air Qual. Res. 17: 513-528.

Wang, Y., Zhuang, G.S., Tang, A.H., Yuan, H., Sun, L.L., Chen, S. and Zheng, A.H. (2005). The ion chemistry and source of $\mathrm{PM}_{2.5}$ aerosol in Beijing. Atmos. Environ. 39: 3771-3784.

Wang, Y., Zhuang, G.S., Zhang, X.Y., Huang, K., Xu, C., Tang, A.H., Chen, J.M. and An, Z.S. (2006). The ion chemistry, seasonal cycle, and sources of $\mathrm{PM}_{2.5}$ and TSP aerosol in Shanghai. Atmos. Environ. 40: 2935-2952.

Wang, Y., Zhuang, G.., Xu, C. and Zheng, A.H. (2007). The air pollution caused by the burning of fireworks during the lantern festival in Beijing, Atmos. Environ. 41: 417-431.

Wang, S., Yan, Q., Yu, F., Wang, Q., Yang, L., Zhang, R. and Yin, S. (2018). Distribution and source of chemical elements in size-resolved particles in Zhengzhou, China: Effects of regional transport. Aerosol Air Qual. Res. 18: 371-385.

Xiao, Z.M., Zhang, Y.F., Hong, S.M., Bi, X.H., Jiao, L., Feng, Y.C. and Wang, Y.Q. (2011). Estimation of the main factors influencing haze, based on a long-term monitoring campaign in Hangzhou, China. Aerosol Air Qual. Res. 11: 873-882.

Yao, X.H., Chan, C.K., Fang, M., Cadle, S., Chan, T., Mulawa, P., He, K.B. and Ye, K.B. (2002). The watersoluble ionic composition of $\mathrm{PM}_{2.5}$ in Shanghai and Beijing, China. Atmos. Environ. 36: 4223-4234.

Zhang, J.S., Chen, Z.Y., Lu, Y.H., Gui, H.Q., Liu, J.G., 
Liu, W.Q., Wang, J., Yu, T.Z., Cheng, Y., Chen, Y., Ge, B.Z., Fan, Y. and Luo, X.S. (2017). Characteristics of aerosol size distribution and vertical backscattering coefficient profile during 2014 APEC in Beijing. Atmos. Environ. 148: 30-41.

Zhang, Q., Canagaratna, M.R., Jayne, J.T., Worsnop, D.R. and Jimenez, J.L. (2005). Time- and size-resolved chemical composition of submicron particles in Pittsburgh: Implications for aerosol sources and processes. J. Geophys. Res. 110: D07S09.
Zhang, R., Wang, G., Guo, S., Zamora, M.L., Ying, Q., Lin, Y., Wang, W., Hu, M. and Wang, Y. (2015). Formation of urban fine particulate matter. Chem. Rev. 115: 3803-3855.

Received for review, July 13, 2018 Revised, December 2, 2018 Accepted, January 16, 2019 